\title{
MODEL PEMBELAJARAN TRANSFORMATIF BERBASIS LEARNING HOW TO LEARN UNTUK PENINGKATAN KREATIVITAS BELAJAR MAHASISWA
}

\author{
Hardika $^{1}$
}

\begin{abstract}
The purpose of this research is to solve the problem of learning related to the effort to improve creativity in learning for students university. Innovation of learning that developed is a transformative model of learning based on princip of learning "how to learn". Research method that used is research and development (RED). The result of this research is transformative learning based on learning "how to learn" able to create flexibility of students to actuate and to express within learning activities so that it able to create creativity of learning.
\end{abstract}

Keywords: Transformative learning, learning how to learn, performance of learning.

\section{A. Pendahuluan}

Pembelajaran bukan sekedar transfer pengetahuan (transfer of knowlendge), tetapi juga merupakan transfer belajar (transfer oflearning) yang mampu menghasilkan transformasi pola pikir dan pola tindak (Novak \& Gowin, 2004; Sulivan, 2001). Dalam perspektif psikologi kognitif, belajar bukan sekedar proses penerimaan informasi secara pasif oleh peserta belajar, tetapi merupakan proses berpikir secara aktif untuk melakukan pemaknaan seluruh pengalaman belajar. Belajar juga bukan sekedar pemenuhan kebutuhan intelektual dengan keterpaksaan, tetapi harus dilakukan dengan penuh kerelaan untuk terlibat dan dilibatkan secara aktif dalam proses interaksi pembelajaran (Knowless, 1988; Harefa, 2005). Keterlibatan mahasiswa dalam pembelajaran harus diarahkan pada terbentuknya kepercayaan diri terhadap potensi dan kemampuan yang dimiliki mahasiswa. Menurut Abdulhak, (2007:523) pembelajaran harus mampu mempersiapkan mahasiswa untuk menampilkan tingkah laku hasil belajar dalam kondisi nyata.

Demikian halnya pada program pendidikan, belajar bukan sekedar untuk mencapai angka-angka kelulusan, tetapi harus mampu menciptakan

1 Dosen Jurusan Pendidikan Luar Sekolah FIP Universitas Negeri Malang. 
kemandirian dan kreativitas belajar serta kebermanfaatan dalam kehidupannya. Kapasitas intelektual (intellectual capacity) yang dibangun dalam sistem pembelajaran harus diarahkan pada peningkatan kapasitas mahasiswa dalam mengelola diri dan lingkungannya. Mahasiswa harus didorong untuk memiliki keberanian dalam melakukan improvisasi dan konstruksi interaksi pembelajaran yang lebih dinamis, baik di dalam maupun di luar kelas. Hal ini perlu dilakukan, sebab gaya dan strategi belajar dari masing-masing mahasiswa berbeda-beda sesuai dengan karakteristik individu dan sosial yang ada di lingkungannya (Pask,1977). Oleh karena itu, kreativitas dan aktivitas belajar harus dimulai dengan penciptaan suasana belajar yang menyenangkan, melibatkan potensi mahasiswa dan lingkungan sekitar dan mengembangkan strategi fasilitasi yang sesuai dengan tujuan pembelajaran (Macaulay, 2000).

Sayangnya, kreativitas belajar yang dimiliki mahasiswa bukan dianggap hal penting oleh sebagian pendidik termasuk pendidikan luar sekolah. Bahkan, sebagian besar pendidik di Indonesia masih menyukai mahasiswa yang memiliki tingkat IQ tinggi daripada kreativitas atau kecerdasan lainnya (Munandar, 1999). Dengan pemahaman semacam ini hampir dapat dipastikan, bahwa pola pembelajaran yang berlangsung selama ini belum akan mampu menunjukkan proses dan hasil belajar yang kreatif dengan disertai ide-ide cerdas, baik dari peserta didik maupun pendidiknya. Padahal, dengan kreativitas yang tinggi peserta didik akan mampu mengelola diri dan lingkungan dengan lebih baik dan mudah menghasilkan apa saja yang dibutuhkan.

Demikian halnya kreativitas belajar dalam pendidikan masih belum erbangun dengan baik. Dalam berbagai kasus pendidikan ditemukan, bahwa proses pembelajaran belum menghasilkan perubahan sikap, perilaku dan wawasan belajar sesuai dengan filosofi belajar dalam pendidikan, yaitu belajar kreatif dengan tingkat kemandirian yang tinggi. Mahasiswa kurang memiliki kemampuan dan kemauan menelaah bahan pembelajaran, sehingga dalam menyikapi pembelajaran hanya dianggap sebagai pemenuhan kewajiban belaka tanpa disertai pemahaman dan pemikiran yang kritis. Keikutsertaan masyarakat dalam pendidikan lebih didasarkan pada keinginan yang kuat untuk mendapatkan ijazah tanpa diikuti oleh semangat dan kesungguhan belajar.

Indikator ini tampak jelas ketika mahasiswa malas menghadiri kegiatan belajar, sering meninggalkan kelas ketika pembelajaran sedang 
berlangsung dan tidak memiliki kesungguhan dalam mengerjakan tugas belajar, baik tugas terstruktur maupun mandiri. Mahasiswa cenderung pasif hanya menunggu dan mendengarkan cerita serta informasi dari dosen tanpa melakukan respon balik. Aktivitas mahasiswa lebih bersifat menjalankan dan mengikuti perintah dosen dari pada inisiatif untuk melakukan perubahan dan peningkatan kapasitas diri secara mandiri. Mahasiswa cenderung hanya akan mengerjakan dan menghadiri kegiatan belajar ketika mengetahui ujian akan dilaksanakan (Supriyono dan Hardika 2007).

Menurut Munandar (1999) dan Makiguchi (1989), kreativitas dapat dibangun melalui sistem pembelajaran yang konstruktif dalam suasana saling menghargai terhadap perilaku dan prestasi masing-masing peserta belajar. Dalam upaya penciptaan kreativitas belajar, hal-hal yang berkenaan dengan potensi mahasiswa harus dieksplorasi dan dikembangkan melalui aktivitas pembelajaran. Minat dan keberbakatan mahasiswa dideteksi dan ditumbuhkembangkan melalui model pembelajaran yang memiliki relevansi dengan upaya penciptaan kreatvitas belajar. Makiguchi (1989:23) mengungkapkan, bahwa untuk membangun kreativitas peserta belajar, penyelenggara pendidikan harus melakukan refleksi total terhadap hakikat tujuan pendidikan (reflection on purpose of education), dasar-dasar nilai pendidikan (fundamentals of education value), melakukan revitalisasi pendidikan (revitalization of education), dan memahami berbagai bahan pembelajaran dan metodologi kependidikan terkini (educational methodology and teaching material). Dalam konteks ini, kreativitas belajar mahasiswa dapat dikembangkan melalui proses eksplorasi dan konstruksi ulang model pembelajaran yang berakar pada karakter dan potensi mahasiswa. Model pembelajaran harus dibangun atas dasar refleksi tujuan pendidikan dan hakikat nilainilai pendidikan, metodologi pembelajaran yang tepat, perangkat dan material pembelajaran yang sesuai dengan misi pembelajaran serta mampu membangkitkan minat dan semangat belajar yang tinggi.

Di samping itu, karakter dosen sebagai fasilitator belum tampak dalam proses interaksi pembelajaran, dosen cenderung melakukan intervensi vertikal tentang pola belajar baku kepada mahasiswa, sehingga kreativitas belajar nahasiswa tidak berkembang. Dosen belum memiliki kemauan dan kemampuan yang memadai dalam perancangan dan implementasi model pembelajaran yang berpusat pada mahasiswa sesuai dengan karakteristik sosial dan pribadi mahasiswa serta filosofi 
pembelajaran di perguruaqn tinggi. Model fasilitasi pembelajaran dalam terminologi pendidikan tinggi masih merupakan model yang "mahal" sehingga proses implementasinya pun belum berjalan dengan baik. Hal ini dikarenakan sebagian besar pendidik masih beranggapan, bahwa model pembelajaran merupakan otoritas mutlak pendidik sehingga pemilihan strategi belajar cenderung bersifat sentralistis oleh dosen tanpa melibatkan potensi mahasiswa.

Berbekal kedewasaan dan pengalaman hidup yang banyak, tentu mahasiswa telah memiliki tanggungjawab dan kemampuan belajar (responsibility and ability to learn) untuk melakukan kegiatan belajar secara bertanggungjawab dan professional (Kamil, 2007). Pengembangan model pembelajaran yang mampu meningkatkan pemahaman dan kemampuan dosen dalam menciptakan kreativitas belajar memiliki relevansi dan urgensi dalam peningkatan kualitas pembelajaran. Kualitas pembelajaran yang baik harus mengutamakan prinsip transformatif dalam setiap interaksi pembelajaran yang dapat dimanfaatkan mahasiswa untuk kehidupannya (King, 2005). Pengembangan model pembelajaran fasilitatif ini dibangun berdasar atas pendapat Havelock (1995) dan Swarchz (2002) yang menekankan pada peran agen pembaharu, yang dalam penelitian ini adalah dosen sebagai fasilitator belajar. Atas dasar argumentasi tersebut di atas, penelitian bertujuan untuk mengembangkan model pembelajaran fasilitatif yang mampu meningkatkan kreativitas belajar mahasiswa program pendidikan.

\section{B. Metode}

Penelitian ini menggunakan pendekatan deskriptif kualitatif dengan rancangan penelitian dan pengembangan pendidikan (educational research and development) versi Borg dan Gall (1983). Tujuan akhir yang ingin dicapai dalam penelitian ini adalah lahirnya produk baru tentang model pembelajaran fasilitatif yang mampu meningkatkan kreativitas belajar peserta didik.

Untuk keperluan uji efektivitas model dipilih dua kelompok peserta matakuliah sebagai kelompok uji dan kelompok pembanding. Penelitian dilakukan dengan menggunakan model kuasi eksperimen melalui "desain dengan kelompok pembanding tanpa pre test" terhadap dua sampel independen dengan hanya melakukan postest, baik terhadap kelompok uji maupun kelompok pembanding terlebih 
dahulu (nonequivalent group post test only design) (Sprinthall, dkk (1991:6869). Hal ini dikarenakan data awal tentang kreativitas belajar pada kelompok uji telah diketahui pada saat dilakukan penelitian pendahuluan (preliminary research). Untuk mengetahui efektivitas hasil uji model dilakukan analisis dengan menggunakan teknik rekam data, catatan harian melalui lembar kreativitas belajar, baik untuk kelompok uji maupun kelompok pembanding.

\section{Hasil}

Model pembelajaran yang selama ini diterapkan pada proses perkuliahan belum mampu menciptakan kreativitas belajar mahasiswa, sehingga mahasiswa sangat bergantung pada eksistensi dan kehadiran dosen di dalam kelas. Oleh karena ketergantungan mahasiswa terhadap dosen sangat tinggi posisi dan mempengaruhi dinamika dan intensitas pembelajaran, maka eksistensi dosen sangat sentral dan dominan dalam proses pembelajaran. Hal ini bertentangan dengan semangat dan filosofi pembelajaran yang sebenarnya lebih mengutamakan proses belajar mandiri dengan model fasilitasi dari dosen.

Model pembelajaran fasilitatif dalam yang dikembangkan dalam penelitian ini secara empirik mampu meningkatkan kreativitas belajar mahasiswa, baik pada tahap perencanaan, pelaksanaan maupun evaluasi pembelajaran. Ada beberapa temuan penting yang harus dikuasai dosen dalam pembelajaran fasilitatif, yaitu (1) filosofi pembelajaran sebagai proses penciptaan kemandirian belajar, (2) hakikat tujuan pembelajaran masyarakat, (3) teknik komunikasi sosial, (4) sistem organisasi pembelajaran orang dewasa, (5) karakteristik mahasiswa, (6) ketersediaan sumber-sumber belajar yang relevan dengan kebutuhan mahasiswa, (7) peran dan posisi dirinya sebagai partner belajar, dan (8) identifikasi kebutuhan dan sumber belajar mahasiswa. Oleh karena itu, untuk memaksimalkan hasil pembelajaran fasilitatif terlebih dahulu diperlukan pelatihan dosen untuk meningkatkan dan memperbaharui pemahamannya tentang fasilitasi pembelajaran.

Kreativitas belajar merupakan salah satu produk belajar yang dapat dicapai melalui rancangan pembelajaran yang berorientasi pada proses dan berakar pada masalah yang dihadapi mahasiswa (problem posing model). Model ini dilakukan dengan cara mendorong terjadinya partisipasi aktif mahasiswa, mengangkat pengalaman mahasiswa 
untuk diuji menjadi bahan belajar/bahan dialog pembelajaran, suasana pembelajaran dirancang penuh kerjasama dengan pelibatan aktif mahasiswa, dan evaluasi dilakukan bersama antara dosen dan mahasiswa melalui uji reflektif.

Substansi model pembelajaran fasilitatif ini meliputi pengembangan peran dosen sebagai fasilitator belajar, penguatan peran mahasiswa sebagai subjek belajar (pelaku dan sasaran utama dalam pembelajaran), pendayagunaan seluruh potensi lingkungan dan pengalaman mahasiswa sebagai sumber pembelajaran, penerapan kata-kata persuasif untuk pembangkitan semangat belajar, penggunaan teknik ice breaking untuk mengurangai ketegangan belajar, penciptaan kreativitas belajar sebagai produk belajar, penerapan evaluasi reflektif untuk peningkatan berpikir kritis (critical thingking).

Model pembelajaran fasilitatif memiliki kelenturan dan feasibilitas untuk diterapkan dalam pembelajaran berkarakter pendidikan nonformal. Akan tetapi implementasi model ini juga dipengaruhi oleh kemampuan dan kemauan dosen dalam memerankan dirinya sebagai fasilitator belajar, kemampuan dalam menerapkan kata-kata persuasif, kemampuan menciptakan suasana segar pembelajaran (ice breaking), peran mahasiswa sebagai subjek belajar, dan kekuatan dosen dalam mengembangkan interaksi pembelajaran. Berkenaan dengan hal tersebut, implementasi peran dosen sebagai fasilitator belajar yang di dalamnya meliputi catalyst, resources linker, process helper, dan solution helper harus diterapkan secara fleksibel sesuai dengan situasi dan kebutuhan mahasiswa. Penerapan fasilitasi pembelajaran harus memperhatikan filosofi "belajar bagaimana cara belajar" (learning how to learn), dengan prinsip belajar melalui pendampingan (learning by facilitating), belajar bersama (learning together), belajar sambil dialog (learning by dialoque), belajar dengan kepercayaan diri (learning by self reliance), belajar melalui lingkungan sosial (learning by social environmental) dan belajar untuk menjadi dirinya (learning to be self).

Oleh karena produk penelitian tentang kreativitas belajar ini berupa performansi mahasiswa dalam proses belajar (learning performance), maka pelibatan dan keterlibatan mahasiswa harus sudah dibangun sejak persiapan pembelajaran. Pelibatan dan keterlibatan mahasiswa dilakukan dengan cara mengajak mahasiswa untuk merekonstruksi hakikat belajar dan pembelajaran, melakukan kontrak belajar, mendiskusikan 
model pembelajaran yang akan diterapkan, membangkitkan kembali semangat belajar melalui kata-kata persuasif dan ice breaking, pemberian beban belajar secara konsisten dan konstruktif, dan evaluasi belajar melalui evaluasi diri (self evaluation), refleksi kritis (critical reflective/ critical thinking), dan penentuan kesadaran atas dirinya sendiri (self determination and self awareness).

Adapun konstruksi model pembelajaran fasilitatif yang dikembangkan dalam penelitian ini dapat digambarkan sebagai berikut:

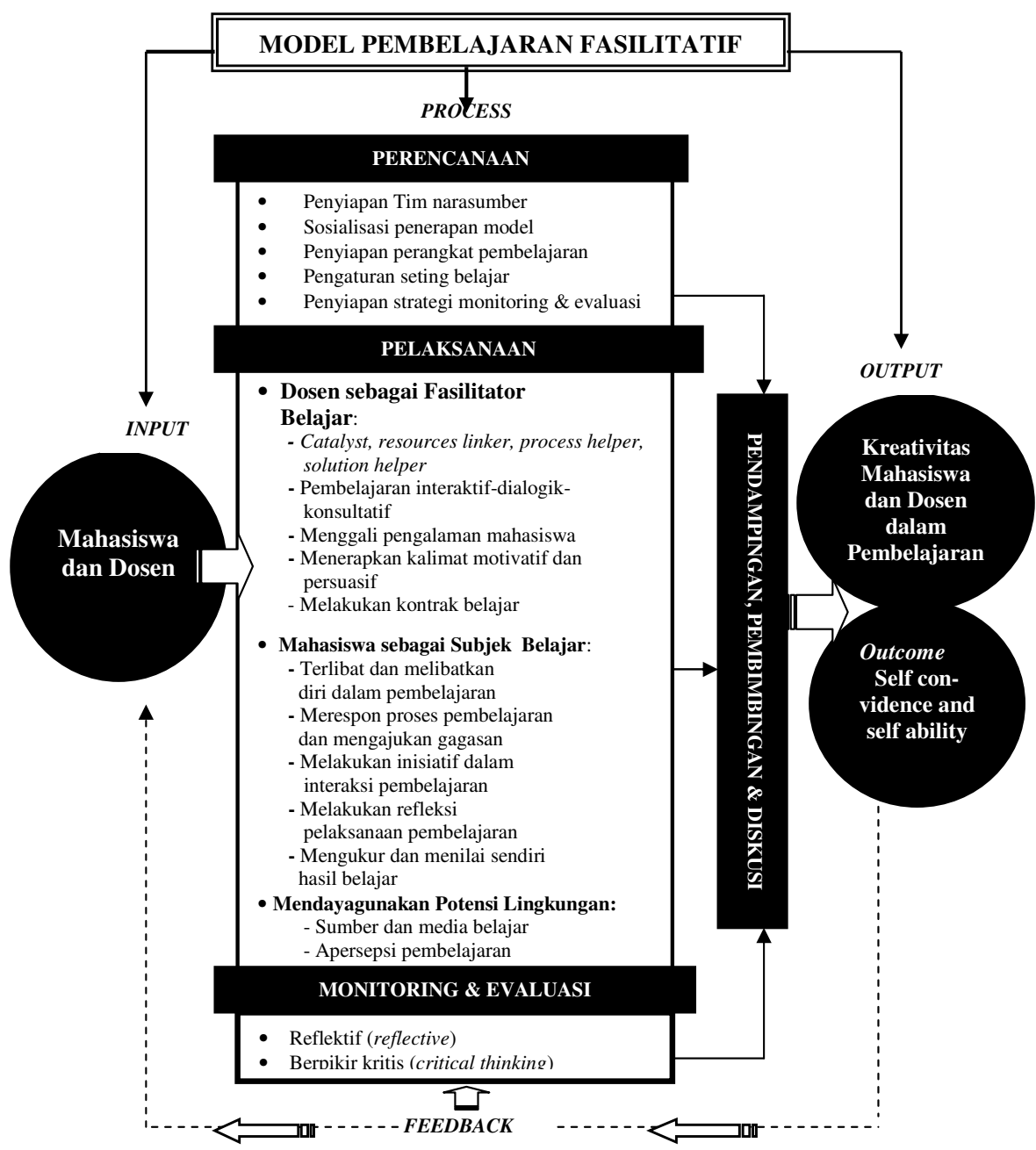


Hardika - Model Pembelajaran Transformatif...

\section{Bahasan}

Optimalisasi peran dosen sebagai fasilitator belajar harus dikembangkan berdasar pada karakter mahasiswa, situasi dan kondisi mahasiswa, dan potensi lingkungan dan pengalaman belajar mahasiswa. Berkaitan dengan prinsip-prinsip pembelajaran fasilitatif, maka ciri-ciri peran dosen dalam pembelajaran adalah (1) dosen selalu merespon perasaan mahasiswa, (2) memanfaatkan ide dan pengalaman mahasiswa untuk merumuskan model pembelajaran, (3) melakukan dialog dan diskusi dengan mahasiswa, (4) menghargai mahasiswa sebagai manusia yang bermartabat, (5) bersikap familiar dan terbuka kepada mahasiswa, (6) merumuskan model pembelajaran sesuai dengan karakteristik mahasiswa dan lingkungan belajar, (7) bersikap empati, respek dan peka terhadap kehendak serta perasaan mahasiswa (Gross, 1999).

Memperhatikan hasil penelitian yang berhasil disimpulkan di depan, ada tiga persoalan yang perlu diperhatikan dalam pengembangan pembelajaran fasilitatif dalam pendidikan -, yaitu (1) penghargaan prestasi dan kelulusan mahasiswa harus dihimpun dari aspek prestasi kenerja dalam melakukan belajar, (2) kualitas dan kelayakan hasil tugas mandiri atau portopolio yang dicapai mahasiswa selama pembelajaran, (3) peningkatan kapasitas dan kapabilitas dosen dalam memahami karakter mahasiswa dan misi pendidikan, (4) pemanfaatan sarana dan medan belajar yang menyenangkan dan bervariasi. Beberapa hal tersebut di atas, secara empirik memiliki kontribusi dalam perubahan sikap dan perilaku mahasiswa untuk lebih aktif, atraktif dan kreatif dalam menjalani pembelajaran. Perubahan sikap dan perilaku belajar yang lebih atraktif dan transformative akan mendorong terjadinya peningkatan motivasi belajar mahasiswa yang lebih produktif (Alderman, 2004).

Menurut Schwarz (2002) pembelajaran fasilitatif memiliki kekuatan dalam menggerakkan dinamika kelompok untuk mencapai tujuan yang diinginkan. Fasilitator berkewajiban membantu meningkatkan efektivitas kegiatan melalui komitmen anggota kelompok yang bersangkutan. Komitmen anggota kelompok merupakan salah satu kunci atau inti dari keberhasilan pembelajaran fasilitatif. The facilitator's main task is to help the group increace effectiveness by improving its process and structure "...the core values of facilitation state that a group is more effective if the group is internally committed to its choice (Schwarz (2002:23). 
Berkenaan dengan efektivitas pembelajaran fasilitatif dalam kelas -, kesepakatan-kesepakatan kelompok yang telah dirumuskan bersama, misalnya tentang isi kontrak belajar harus menjadi komitmen bersama melalui peningkatan dan pemberdayaan kelas. Kelas merupakan medan dan wadah belajar yang dianggap paling relevan dalam pembelajaran pendidikan luar sekolah yang berbasis fasilitatif. Proses kelompok bukan berarti meninggalkan intensitas dan kapasitas individu mahasiswa, tetapi proses belajar dibangun atas dasar saling membelajarkan dan saling menghargai sesama mahasiswa dalam sistem kelompok. Menurut Hackman, dalam (Schwarz, 2002), ada tiga faktor yang berkontribusi dalam peningkatan efektivitas kelompok, yaitu proses kelompok (group process), struktur kelompok (group structure) dan konteks kelompok (group context). Kelompok harus mampu bergerak dan bekerja dengan baik, memiliki struktur tatanan dan pengelolaan yang benar, dan memiliki relevansi atau memperhatikan konteks dan tujuan kelompok yang bersangkutan. Berikut disajikan salah satu model pemecahan masalah pembelajaran berbasis fasilitasi.

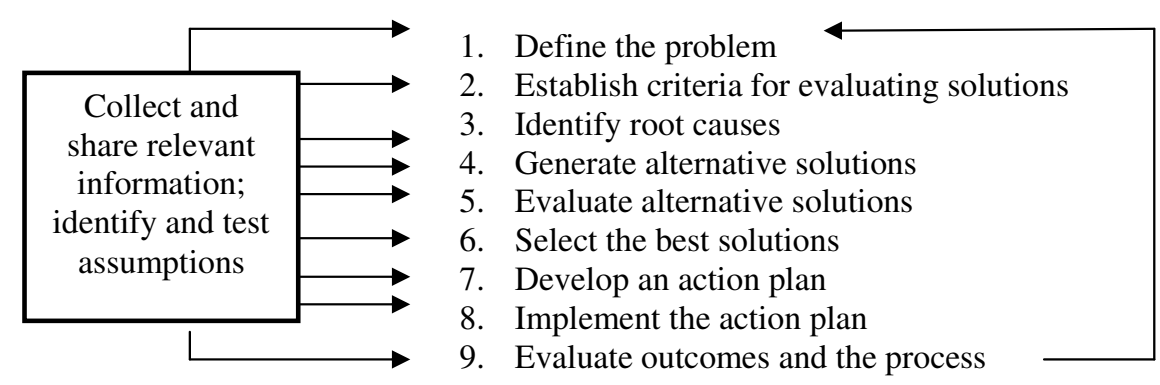

Sumber: Schwarz (2002:221)

Efektivitas pembelajaran dalam pencapaian hasil belajar harus dibangun dengan mendinamisasikan dan menggerakkan sistem belajar, melalui pengelolaan yang lebih baik, kepengurusan belajar yang profesional, yaitu kepengurusan yang memiliki kapasitas dan kapabilitas dalam pemberdayaan mahasiswa. Terkait pembelajaran fasilitatif, proses, struktur dan konteks kelompok harus didasarkan pada peningkatan kapasitas dan profesionalitas dan ketersediaan dosen, kelengkapan organ kepengurusan kelas, ketersediaan narasumber teknis, 
dan profesionalitas kerja tim administrasi. Dalam kaitan pembelajaran model, perlu juga mulai dipikirkan tim peneliti dan pengembang (litbang) yang bertugas untuk mengkaji berbagai perkembangan dan issue tentang pembelajaran pendidikan -.

Pengembangan kretivitas belajar melalui pembelajaran fasilitatif memiliki keterkaitan yang kuat dengan upaya perubahn sikap belajar. Pembahasan tentang sikap belajar kreatif dalam kaitannya dengan implementasi model pembelajaran fasilitatif, tentu akan melibatkan faktor yang mempengaruhi terjadinya perubahan dan pembentukan sikap seseorang terhadap objek, yaitu hal-hal yang berkenaan dengan relevansi, kemenarikan, dan objek sikap, yang dalam hal ini adalah model pembelajaran fasilitatif.

Pambentukan dan perubahan sikap mahasiswa tidak terjadi dengan sendirinya, tetapi senantiasa berlangsung dalam interaksi antar manusia dan berkenaan dengan model pembelajaran yang diterapkan. Salah satu faktor yang mempengaruhi terjadinya perubahan sikap mahasiswa adalah adanya pengaruh atau respon dari luar yang mampu mempengaruhi sikap yang telah lebih dahulu bercokol dalam diri seseorang. Namun demikian, bagaimanapun besarnya pengaruh dari luar, apabila faktor internal mahasiswa belum mau menerimanya, maka tidak akan menghasilkan perubahan sikap baru. Oleh karena itu, model pembelajaran fasilitatif sebagai objek sikap, tentu akan direspon oleh mahasiswanya jika memiliki kemenarikan, relevansi, dorongan eksternal dan internal mahasiswa. Berkenaan dengan uraian di atas, maka dalam pembahasan ini perlu diungkap terlebih dahulu hal-hal yang berkaitan dengan hakikat sikap.

Kreativitas bukan murni perilaku bawaan atau bakat, tetapi merupakan hasil dari proses pendidikan yang melibatkan potensi lingkungan secara optimal, kekuatan pendidik dalam mengubah potensi lingkungan sebagai modal belajar, dan rekayasa karakter peserta didik sebagai subjek belajar. Dengan kata lain, kreativitas akan muncul ke permukaan setelah melalui proses rekayasa sosial (social enginering) dengan melibatkan seluruh unsur lingkungan yang terkait dengan subjek belajar dan sistem pembelajaran. Rekayasa sosial yang dimaksud dalam pembahasan ini adalah terciptanya suasana kebudayaan creativogeneic. Creativogoneic menurut Silvano Arieti, dalam (Munandar, 1999:176) adalah suatu kebudayaan yang menunjang, memupuk dan 
memungkinkan berkembangnya kreativitas seseorantg dalam sistem kehidupannya.

Dibanding dengan substansi pembelajaran yang lain, kreativitas masih tergolong baru sebagai bidang aktivitas akademik yang bersistem dan menjadi kajian riset yang bersifat empiris. Kajian terhadap kreativitas baru diungkap secara empiris dalam kontek pembelajaran setelah terjadi Perang Dunia kedua melalui pidato bersejarah Guilford tahun 1950 sebagai Presiden American Psychological Association (APA), yang menekankan "the appalling neglect" tentang pentingnya studi kreativitas dan mengingatkan akan kebutuhan kreativitas di masyarakat melalui berbagai sistem pembelajaran dan pendidikan. Di samping itu, peluncuran Sputnik tahun 1957 dianggap sebagai ancaman bagi Amerika untuk mempertahankan keunggulannya di bidang teknologi, yang akhirnya mendorong Amerika mengobarkan pendidikan yang berbasis pada pengembangan kreativitas peserta didik. Kedua peristiwa tersebut dianggap oleh kalangan pendidik sebagai cikal bakal lahirnya demensi kreativitas sebagai kajian empiris dalam berbagai sistem pembelajaran (Munandar, 1999).

Dalam perkembangan selanjutnya, kreativitas telah menjadi fokus kajian penting dalam sistem pendidikan dan menyebar ke berbagai aktivitas manusia baik dalam sistem pembelajaran maupun dunia kerja yang lain. Bahkan, kreativitas merupakan bagian integral yang tidak terpisahkan dari sistem kecerdasan seseorang selain kecerdasan intelektual, emosional, sosial, dan spiritual. Prinsip dasar kreativitas dapat dilacak dari kemampuan berpikir konvergen dan berpikir divergen. Pemikiran konvergen dengan suatu penalaran yang logis dan mengarah pada jawaban 'benar' merupakan proses yang mendasari pengukuran kecerdasan tradisional, sedangkan pemikiran divergen adalah corak pemikiran yang menghasilkan bermacam-macam gagasan dan ini merupakan indikator paling nyata dari kreativitas.

Salah satu masalah yang kritis dalam pengembangan kreativitas adalah soal kriteria. Pada umumnya para ahli sepakat, bahwa tidak mudah merumuskan kriteria yang tepat dalam menemukan dan mengembangkan kreativitas. Makiguchi (1989) mengingatkan, bahwa tidak mungkin menemukan kriteria kreativitas yang tidak bercampur dengan ciri-ciri dan perilaku manusia lainnya, terutama intelegensi, sebab kreativitas merupakan konstruk yang multi demensional. Apalagi 
hasil riset yang telah dilakukan membuktikan, bahwa sebagian besar guru masih menyenangi anak yang memiliki IQ tinggi dibanding dengan anak yang memiliki dasar kreativitas bagus. Padahal, kenyataan empirik menunjukkan bahwa kreativitas memiliki kelebihan dalam banyak hal termasuk kemampuannya dalam menyelesaikan masalah dengan baik sebagaimana masalah yang diselesaikan oleh mereka yang memiliki IQ tinggi (Munandar, 1999). Untuk menciptakan suasana yang mendukung terciptanya kreativitas belajar, fasilitator belajar harus mampu menempatkan dirinya sebagai pendamping belajar yang baik, dengan berperan sebagai catalyst, process helper, resources linker, dan solution helper. Dengan cara ini dosen bukan sekedar melaksanakan transfer of knowledge kepada peserta didik, tetapi lebih ditekankan pada transfer of process.

\section{E. Kesimpulan}

\section{Kesimpulan}

Model pembelajaran transformative dalam program pembelajaran yang dikembangkan dalam penelitian ini mampu meningkatkan kreativitas belajar mahasiswa, baik pada tahap perencanaan, pelaksanaan maupun evaluasi pembelajaran. Hasil analisis membuktikan, bahwa kreativitas belajar mahasiswa program pendidikan yang menggunakan model pembelajaran fasilitatif berbeda lebih tinggi dibanding kreativitas belajar yang tidak menggunakan model pembelajaran fasilitatif. Dengan kreativitas belajar yang dimiliki mahasiswa, maka proses pembelajaran belangsung lebih dinamis, atraktif, dan menyenangkan.

Substansi model pembelajaran transformative berbasis learning how to learn ini meliputi pengembangan peran dosen sebagai fasilitator belajar, penguatan peran mahasiswa sebagai subjek belajar (pelaku dan sasaran utama dalam pembelajaran), pendayagunaan seluruh potensi lingkungan dan pengalaman mahasiswa sebagai sumber pembelajaran, penerapan kata-kata persuasif untuk pembangkitan semangat belajar, penggunaan teknik ice breaking untuk mengurangai ketegangan belajar, penciptaan kreativitas belajar sebagai produk belajar, penerapan evaluasi reflektif untuk peningkatan berpikir kritis (critical thingking).

Berkenaan dengan kesimpulan hasil penelitian ini, ada beberapa hal yang harus dikuasai dosen sebagai fasilitator belajar, yaitu (1) proses penciptaan kemandirian belajar, (2) pemberdayaan mahasiswa 
dalam aktivitas pembelajaran, (3) teknik komunikasi sosial, (4) sistem organisasi pembelajaran orang dewasa, (5) karakteristik mahasiswa orang dewasa, (6) ketersediaan sumber-sumber belajar yang relevan dengan kebutuhan mahasiswa, (7) peran dan posisi dosen sebagai pendamping belajar, dan (8) identifikasi kebutuhan dan sumber belajar mahasiswa. Oleh karena itu, untuk memaksimalkan proses fasilitasi pembelajaran terlebih dahulu diperlukan pelatihan dosen untuk meningkatkan, memperbaharui dan mengkonstruksi ulang (reconstruction) pengetahuan dosen tentang model fasilitasi pembelajaran.

\section{Saran}

Berdasarkan pada temuan tersebut, direkomendasikan kepada dosen pembina matakuliah untuk meningkatkan kapasitas dan kapabilitas dirinya sebagai fasilitator belajar (change agent on learning), sehingga proses pembelajaran yang dibangun dosen memiliki kekuatan untuk menghasilkan kekuatan intelektual mahasiswa sesuai dengan filosofi dan misi pembelajaran di perguruasn tinggi. Peningkatan kapasitas dan kapabilitas dosen sebagai pendidik di perguruan tinggi bias dilakukan melalui pembentukan kelompok diskusi, lesson study dan peer teaching.

\section{DAFTAR PUSTAKA}

Abdulhak, I. (2007). Teknologi Pendidikan dalam Ilmu dan Aplikasi Pendidikan. Bandung: Pedagogiana Press.

Aldeman, M. Kay. (2004). Motivation for Achievement, Possibilities for Teaching and Learning. London. Lowrence Erlbaum Associatis Publishers.

Borg, W.R. \& Gall, M.D. (2003). Educational Research: An Introduction. Third Edition. New York: Longman.

Gross R.(1999); Peak Learning How to Create Your Own Lifelong Education Program for Personal Enjoyment and Profesional Success. New York, Jeremy P.Tarcher/Putnam a member of Penguin Putnam Inc.

Harefa, A. (2005). Menjadi Manusia Pembelajar (On Becoming A Learner): Pemberdayaan Diri, Transformasi Organisasi dan Masyarakat Lewat Proses Pembelajaran. Jakarta: PT Kompas Media Nusantara. 
Hardika - Model Pembelajaran Transformatif...

Havelock, RG \& Zlotolow, S. (1995). The Change Agent's Guide. Second Edition. New

Jersey: Educational Technology Publications Englewood Cliffs.

Kamil, M. (2007). Teori Andragogi, dalam Ilmu dan Aplikasi Pendidikan. Bandung: Pedagogiana Press.

King, K.P. (2005). Bringing Transformative Learning to Life. Malabar, Florida: Krieger Publising Company.

Knowles, M.S. (1988). The Adult Learner A Neglected Species. Houston: Gulf Publishing Company.

Macaulay, C. (2000). Transfer of Learning in Professuional and Vocational Education. Edinburgh: University of Edinburgh.

Makiguchi, T. (1989). Education for Creative Living. dalam Bethel, DM (editor). Iowa University Press/Ames.

Munandar, S.C.U. (1999). Creativity and Education: A Studi of TheRelationshis Between Measures of Creative Thinking and A Number of Educational Variables in Indonesian Primary and Junior Secondary Schools. Jakarta: Ditjen Dikti Depdikbud.

Novak, J.D.\& Gowin, B.D. (2004). Learning How To Learn. Cambridge University Press.

Pask, G. (1977). Styles and Strategies of Learning. British Joernal of Educational Psychology. Ed. 46.

Schwarz, R. (2002). The Skilled Facilitator: A Comprehenvive Resource for Consultants, Facilitators, Managers, and Coaches. San Francisco. Jossey Bass A Willey Company.

Sprinthall, RC, Schumutte, GT, Sirois, L. (1991). Understanding Educational Research. New Jersey. Prentice Hall Inc.

Sullivan, E .O'. (2001). Transformative Learning. Educational Vission for the $21^{\text {st }}$ Century. Toronto: Published in Association with University of Toronto Press 